\title{
Adrenomedullin Is Necessary to Resolve Hyperoxia-Induced Experimental Bronchopulmonary Dysplasia and Pulmonary Hypertension in Mice
}

Renuka T. Menon, ${ }^{*}$ Amrit Kumar Shrestha, ${ }^{*}$ Corey L. Reynolds, ${ }^{\dagger}$ Roberto Barrios, ${ }^{\ddagger}$ Kathleen M. Caron, ${ }^{\S}$ and Binoy Shivanna*

From the Section of Neonatology, ${ }^{*}$ Department of Pediatrics, and Mouse Phenotyping Core, ${ }^{\dagger}$ Baylor College of Medicine, Houston, Texas; the Department of Pathology and Genomic Medicine, ${ }^{\ddagger}$ Houston Methodist Hospital, Houston, Texas; and the Department of Cell Biology and Physiology, ${ }^{\S}$ University of North Carolina, Chapel Hill, North Carolina

\author{
Accepted for publication \\ November 25, 2019. \\ Address correspondence to \\ Binoy Shivanna, M.D., D.M., \\ Ph.D., Neonatology Section, \\ Baylor College of Medicine, \\ 1102 Bates Ave., FC530.01, \\ Houston, TX 77030. E-mail: \\ shivanna@bcm.edu.
}

\begin{abstract}
Bronchopulmonary dysplasia (BPD)-associated pulmonary hypertension (PH) is an infantile lung disease characterized by aberrant angiogenesis and impaired resolution of lung injury. Adrenomedullin (AM) signals through calcitonin receptor-like receptor and receptor activity-modifying protein 2 and modulates lung injury initiation. However, its role in lung injury resolution and the mechanisms by which it regulates angiogenesis remain unclear. Consequently, we hypothesized that $\mathrm{AM}$ resolves hyperoxia-induced $\mathrm{BPD}$ and $\mathrm{PH}$ via endothelial nitric oxide synthase (NOS3). AM-sufficient $\left(A D M^{+/+}\right)$ or -deficient $\left(A D M^{+/-}\right)$mice were exposed to normoxia or hyperoxia through postnatal days (PNDs) 1 to 14 , and the hyperoxia-exposed mice were allowed to recover in normoxia for an additional 56 days. Lung injury and development and $\mathrm{PH}$ were quantified at different time points. Human pulmonary microvascular endothelial cells were also used to examine the effects of AM signaling on the NOS3 pathway and angiogenesis. Lung blood vessels and NOS3 expression decreased and the extent of hyperoxia-induced $\mathrm{BPD}$ and $\mathrm{PH}$ increased in $A D M^{+/-}$mice compared with $A D M^{+/+}$mice. Hyperoxiainduced apoptosis and PH resolved by PND14 and PND70, respectively, in $A D M^{+/+}$mice but not in $A D M^{+/-}$mice. Knockdown of $A D M$, calcitonin receptor-like receptor, and receptor activity-modifying protein 2 in vitro decreased NOS3 expression, nitric oxide generation, and angiogenesis. Furthermore, NOS3 knockdown abrogated the angiogenic effects of AM. Collectively, these results indicate that AM resolves hyperoxic lung injury via NOS3. (Am J Pathol 2020, 190: 711-722; https://doi.org/10.1016/ j.ajpath.2019.11.011)
\end{abstract}

Bronchopulmonary dysplasia (BPD) is a chronic lung disease of preterm infants that results from aberrant lung development. $^{1}$ A total of $12 \%$ to $39 \%$ of infants with moderate to severe BPD develop pulmonary hypertension $(\mathrm{PH}) .^{2}$ The pathophysiology of $\mathrm{PH}$ in BPD includes decreased pulmonary blood vessels, endothelial cell dysfunction, and increased remodeling of resistance pulmonary arteries. ${ }^{3}$ The short- and long-term morbidity and mortality are significantly increased in patients with BPD who develop $\mathrm{PH}^{3,4}$ Moreover, this disease lacks specific therapies, emphasizing the need for further research.
Adrenomedullin (AM) is a peptide present in high concentrations in richly vascularized organs. Calcitonin receptor-like receptor (Calcrl) and receptor

Supported by NIH grants HD073323 (B.S.), HL139594 (B.S.), U54 HG006348 (Mouse Phenotyping Core at Baylor College of Medicine), DK56338, CA125123 (Integrated Microscopy Core at Baylor College of Medicine), and P30DK056338 (Digestive Disease Center Core at Baylor College of Medicine); Cancer Prevention and Research Institute of Texas grants RP150578 and RP170719 (Integrated Microscopy Core at Baylor College of Medicine); American Heart Association award BGIA-20190008 (B.S.); American Lung Association award RG-349917 (B.S.); and Texas Children's Hospital pediatric pilot award (B.S.).

Disclosures: None declared. 
activity-modifying protein (RAMP) 2 are coreceptors that mediate AM signaling. ${ }^{6}$ AM supports proliferation, growth, and survival of endothelial cells. ${ }^{7,8}$ Histologic and gene expression analyses of human and murine lung tissues demonstrate the co-expression of AM and its receptors in endothelial cells and epithelial cells of the airway and alveoli, suggesting that AM signals through the autocrine and paracrine pathways. ${ }^{9-11}$ AM also regulates fetal pulmonary circulation ${ }^{12}$ and promotes alveolar regeneration and lung vascularization in a mouse model of pulmonary emphysema. ${ }^{13}$ Elevated expression of AM-signaling components in the cells that modulate proliferation and differentiation combined with increased AM expression during the crucial lung development period ${ }^{14-16}$ suggest a mechanistic link between AM signaling and lung development, injury, and repair. AM mediates its biological effects partly via endothelial nitric oxide synthase (NOS3). ${ }^{17,18}$ Furthermore, AM plays a role in the initiation of hyperoxia-induced BPD and PH. ${ }^{19}$ However, the following roles of AM in the lung need further study: i) role of endogenous AM signaling in the resolution of neonatal hyperoxia-induced lung injury; ii) regulation of angiogenesis by AM in the lungs of preterm infants; and iii) interactions between AM and NOS3 in the developing lung. This study is designed to elucidate these functions of AM in neonatal lung.

Supplemental oxygen is a necessary and pivotal therapy to correct hypoxemia in preterm infants; however, oxidative stress and inflammation associated with this therapy contribute to BPD and PH. Mouse lungs at birth are structurally similar to those of a preterm infant born at 25 to 26 weeks ${ }^{20}$; therefore, mice are one of the most commonly used animals to model BPD. Furthermore, several studies ${ }^{21-25}$ have found that hyperoxia-exposed neonatal mice develop lung injury similar to that of human BPD with PH. Using this model, we hypothesized that AM is necessary to resolve hyperoxia-induced BPD and PH via NOS3 in neonatal mice. Fetal human pulmonary microvascular endothelial cells (HPMECs) were also chosen to understand the role of AM signaling in angiogenesis of infantile lungs because proliferation and maturation of pulmonary microvascular endothelial cells are crucial for alveolarization ${ }^{26}$ and these cells are enriched with AM and its signaling receptors. ${ }^{27}$

\section{Materials and Methods}

\section{In Vivo Studies}

\section{Animals}

This study was approved and conducted in strict accordance with the federal guidelines for the humane care and use of laboratory animals by the Institutional Animal Care and Use Committee of Baylor College of Medicine. Dr. Kathleen Caron (University of North Carolina, Chapel Hill, NC) kindly provided us the $A D M$-haplodeficient $\left(A D M^{+/-}\right)$mice on a $129 / \mathrm{SvEv}$ background. The generation of these mice was previously described. ${ }^{28}$ These $A D M^{+/-}$mice were backcrossed onto C57BL/6J wild-type mice (catalog number 000664; The Jackson Laboratory, Bar Harbor, ME) for 12 generations to obtain $A D M^{+/-}$mice on a $\mathrm{C} 57 \mathrm{BL} / 6 \mathrm{~J}$ background for these experiments. Because of the embryonic lethality of $A D M^{-1-}$ mice, we used $A D M^{+/-}$mice for these studies.

\section{Hyperoxia Experiments}

Within 24 hours of birth, male and female $A D M^{+/-}$pups and their wild-type littermates $\left(A D M^{+/+}\right)$were exposed to $70 \%$ oxygen (hyperoxia) for 14 days and then allowed to recover in $21 \%$ oxygen (normoxia) for up to 56 days. A separate group of male and female $A D M^{+/-}$and $A D M^{+/+}$ pups were maintained in normoxia for up to 70 days. Oxygen exposures were conducted in Plexiglas chambers, and the dams were rotated between normoxic and hyperoxic conditions as previously described. ${ }^{24}$

Tissue Preparation for Gene and Protein Expression, Lung Morphometry, and Immunohistochemistry Studies

The animals were euthanized on postnatal day (PND) 7 or PND14, and their right and left lungs were immediately snap frozen in liquid nitrogen and stored at $-80^{\circ} \mathrm{C}$ for the extraction of protein and RNA, respectively. For lung morphometry and immunohistochemistry studies, the mice were euthanized on PND14 or PND28, and their lungs were inflated and fixed via the trachea with $10 \%$ formalin at $25 \mathrm{~cm} \mathrm{H}_{2} \mathrm{O}$ pressure for lung morphometry studies. $^{24}$

Analysis of Alveolarization and Pulmonary Vascularization Alveolar development in selected mice was evaluated on PND14 or PND28 by measuring radial alveolar counts and mean linear intercepts. Pulmonary vessel density was also determined in these animals based on immunohistochemical staining for von Willebrand factor (vWF). ${ }^{24}$ The number of vWF-stained blood vessels with a diameter of $<150 \mu \mathrm{m}$ was quantified from at least 10 random nonoverlapping fields for each animal as described previously ${ }^{24}$ to determine the pulmonary vascular density.

\section{Real-Time RT-PCR Assays}

Total RNA was isolated from the lungs at PND7 and reverse transcribed to cDNA. ${ }^{29}$ Real-time quantitative RT-PCR analysis was performed using TaqMan gene expression master mix (catalog number 4369016; Thermo Fisher Scientific, Grand Island, NY) and the following gene-specific primers: $A D M$ (AP7DPHX, PN4331348), BAX (Mm00432051_m1), TNFRSF10B (Mm00457866_m1), NOS3 (Mm00435217 _m1; alias eNOS), and GAPDH (Mm99999915_g1).

\section{Immunoblot Assays}

The whole lung protein from the experimental animals was extracted and subjected to immunoblotting as previously described $^{30}$ with the following antibodies: $\beta$-actin (catalog number sc-47778, dilution 1:5000; Santa Cruz Biotechnologies, 
Santa Cruz, CA) and cleaved caspase 3 (Ab13847, dilution 1:500; Abcam, Cambridge, MA).

\section{Echocardiography}

The indexes of PH were assessed by performing echocardiography ${ }^{24}$ on PND28 or PND70 using the VisualSonics Vevo 2100 machine (FUJIFILM VisualSonics Inc., Toronto, ON, Canada) and a 40-MHz linear transducer. Pulsed-wave Doppler recording of the pulmonary blood flow was obtained at the level of the aortic valve in the parasternal right ventricular outflow view ${ }^{31}$ to measure pulmonary acceleration time (PAT) and right ventricle (RV) ejection time (ET). The RV systolic pressure (RVSP) was calculated using the regression formula $\mathrm{RVSP}=64.5-(83.5 \times \mathrm{PAT} / \mathrm{ET}){ }^{31}$

\section{Immunohistochemistry Studies}

The lungs processed for morphometry studies at PND14 or PND28 were subjected to immunohistochemistry studies to determine the collagen content of the lungs. The paraffinembedded tissues were deparaffinized and subjected to Masson trichrome staining (catalog number 87019; Thermo Scientific, Waltham, MA; and Richard-Allan Scientific, Waltham, MA) according to the manufacturer's recommendations. Collagen was identified by the blue staining and quantified using ImageJ software version $1.8(\mathrm{NIH}$, Bethesda, MD; http://imagej.nih.gov/ij).

\section{In Vitro Studies}

\section{Cell Culture and Treatment}

Fetal HPMECs extracted from a donor whose gestational age was 18 weeks were obtained from ScienCell research Laboratories (catalog number 3000; San Diego, CA) and grown according to the manufacturer's protocol. Cells between passages five and eight were used for all experiments. The HPMECs were validated by immunostaining with vWF. For angiogenesis assays, the cells were treated with $100 \mathrm{nmol} / \mathrm{L}$ AM (catalog number H2932; American Peptide, Sunnyvale, CA) or phosphate-buffered saline.

\section{siRNA Transfection Experiments}

Transfections were performed with either $50 \mathrm{nmol} / \mathrm{L}$ control siRNA (d-001810) or $50 \mathrm{nmol} / \mathrm{L}$ target gene-specific siRNAs (ADM: L-011199; Calcrl: L-004350; RAMP2: L-003701; and NOS3: L-006490; Dharmacon, Lafayette, CO) using Lipofectamine RNAiMAX (catalog number 13778030; Life Technologies, Grand Island, NY). siRNA-mediated knockdown of specific target genes were confirmed by real-time RTPCR analysis and immunoblotting as described previously. ${ }^{27}$

\section{Real-Time RT-PCR Assays}

Real-time quantitative RT-PCR analysis was performed with 7900HT Real-Time PCR System using TaqMan gene expression master mix and gene-specific primers (ADM: Hs00969450_g1; Calcrl: Hs00907738_m1; NOS3:
Hs01574665_m1; GAPDH: Hs02758991_g1; and RAMP2: Hs01006937-g1) as described previously. ${ }^{27}$

\section{Immunoblot Assays}

Radioimmunoprecipitation assay lysis buffer system (catalog number sc-24948; Santa Cruz Biotechnologies) was used to extract whole cell protein. The extracted protein was subjected to immunoblotting with the following antibodies: $\beta$-actin (catalog number sc-47778, dilution 1:1000; Santa Cruz Biotechnologies) and NOS3 (catalog number 9572, dilution 1:1000; Cell Signaling, Danvers, MA), and the immunoblots were quantified as previously described. ${ }^{30}$

\section{Tubule Formation Assay}

Matrigel assay was used to determine tubule formation. ${ }^{32}$ HPMECs were transfected with control or target gene-specific siRNA for 24 hours and loaded on top of growth factor-reduced Matrigel in a 96-well plate. Tubule formation was quantified 18 hours after seeding the cells on to the Matrigel. In addition, cells transfected with control or NOS3siRNA for 6 hours were treated with $100 \mathrm{nmol} / \mathrm{L}$ AM or phosphate-buffered saline for 30 minutes before they were subjected to tubule formation assay. Phase contrast imaging was performed as a single time point scan with a $4 \times(2.82 \mu \mathrm{m}$ per pixel) objective with one field of view to capture all the tubules in a well using the IncuCyte instrument (IncuCyte S3 Live-Cell analysis system; Sartorius, Goettingen, Germany). A segment connecting two branching points was considered as a tubule, and the number of tubules in each well was quantified using the ImageJ software version 1.8.

\section{Assay to Quantify Nitric 0xide Generation}

The cells grown to $60 \%$ confluence in $96-$ well plates were transfected with control or target gene-specific siRNAs for 48 hours. The transfected cells were treated with $5 \mu \mathrm{mol} / \mathrm{L}$ A23187 (catalog number C7522; Sigma-Aldrich, St. Louis, MO), a calcium ionophore, or the vehicle, phosphate-buffered saline for 1 hour and then stained with $10 \mu \mathrm{mol} / \mathrm{L}$ 4-amino-5methylamino-2 ${ }^{\prime}, 7^{\prime}$-difluorofluorescein diacetate (DAF-FM diacetate; catalog number D23844; Thermo Scientific) for 1 hour. The stained cells were washed twice, and the DAF-FM diacetate fluorescence intensity was measured at excitation and emission wavelengths of $485 \mathrm{~nm}$ and $525 \mathrm{~nm}$, respectively, using a Spectramax M3 fluorescence microplate reader.

\section{Statistical Analysis}

GraphPad Prism software version 5 (GraphPad Software, La Jolla, CA) was used to analyze the results, and the data are expressed as means \pm SD. $P<0.05$ was considered significant. At least two separate in vivo experiments were performed for each measurement. The effects of gene, exposure, and their associated interactions on outcome variables, including alveolarization, pulmonary angiogenesis, and indexes of $\mathrm{PH}$, were analyzed using analysis of variance. Multiple comparison testing by the post hoc Bonferroni test was performed if statistical significance of either variable or interaction was 
noted by analysis of variance. At least three in vitro separate experiments were performed for each measurement. Gene knockdown and tubule formation results were assessed by $t$-test, whereas the interaction between AM treatment and NOS3 knockdown on tubule formation and nitric oxide generation was analyzed by analysis of variance.

\section{Results}

$A D M^{+/-}$Mice Have Decreased Alveolarization and Lung Vascularization

$A D M^{+/-}$mice were identified by both genotyping and realtime RT-PCR analysis. Consistent with previous studies, ${ }^{33,34}$ the lung $A D M$ mRNA levels decreased by twofold in $A D M^{+/-}$mice (Figure $1 \mathrm{H}$ ). Furthermore, neonatal $A D M^{+-}$mice had few (Figure $1, \mathrm{~A}, \mathrm{~B}$, and $\mathrm{E}$ ) enlarged alveoli (Figure 1, A, B, and F) and reduced $v W F-$ positive lung vasculature (Figure 1, C, D, and G) compared with $A D M^{+++}$mice at normoxic conditions, indicating that $A D M^{+/-}$mice have decreased alveolarization and lung vascularization at baseline.

\section{ADM Deficiency Potentiates Hyperoxia-Induced} Alveolar and Pulmonary Vascular Simplification in Neonatal Mice

Neonatal mice (PND14) exposed to hyperoxia for 14 days had decreased radial alveolar counts and increased mean linear intercepts, indicating that there were fewer alveoli with larger diameter compared with normoxia-exposed (Figure 2, A, B, C, D, I, and J) animals. Similarly, these mice had a decreased number of vWF-stained lung blood vessels compared with normoxia-exposed mice (Figure 2, E, F, G, H, and K). At PND7, hyperoxia exposure decreased lung NOS3 mRNA expression (Figure 2L). However, the extent of hyperoxia-induced interruption in lung developmental process and repression of NOS3 mRNA expression was significantly greater in $A D M^{+/-}$mice than $A D M^{+/+}$mice (Figure 2).

\section{ADM Deficiency Potentiates Long-Term Lung Developmental Deficits Caused by Neonatal Hyperoxia}

Adolescent mice (PND28) exposed to neonatal hyperoxia had decreased radial alveolar counts and increased mean linear intercepts, indicating that there were fewer alveoli with larger diameter compared with normoxia-exposed (Figure 3, A, B, C, D, I, and J) animals. Similarly, these mice had a decreased number of vWF-stained lung blood vessels compared with normoxia-exposed mice (Figure 3, E, F, G, H, and K). These findings reinforce the conclusions of several preclinical studies. ${ }^{25,35-37}$ However, the extent of hyperoxia-induced long-term lung developmental deficits was significant greater in $A D M^{+/-}$mice than $A D M^{+/+}$mice (Figure 3).

\section{ADM Deficiency Potentiates Experimental PH Caused by Neonatal Hyperoxia}

Transthoracic high-resolution echocardiographic studies were performed and RV systolic intervals (indexes of $\mathrm{PH}$ )
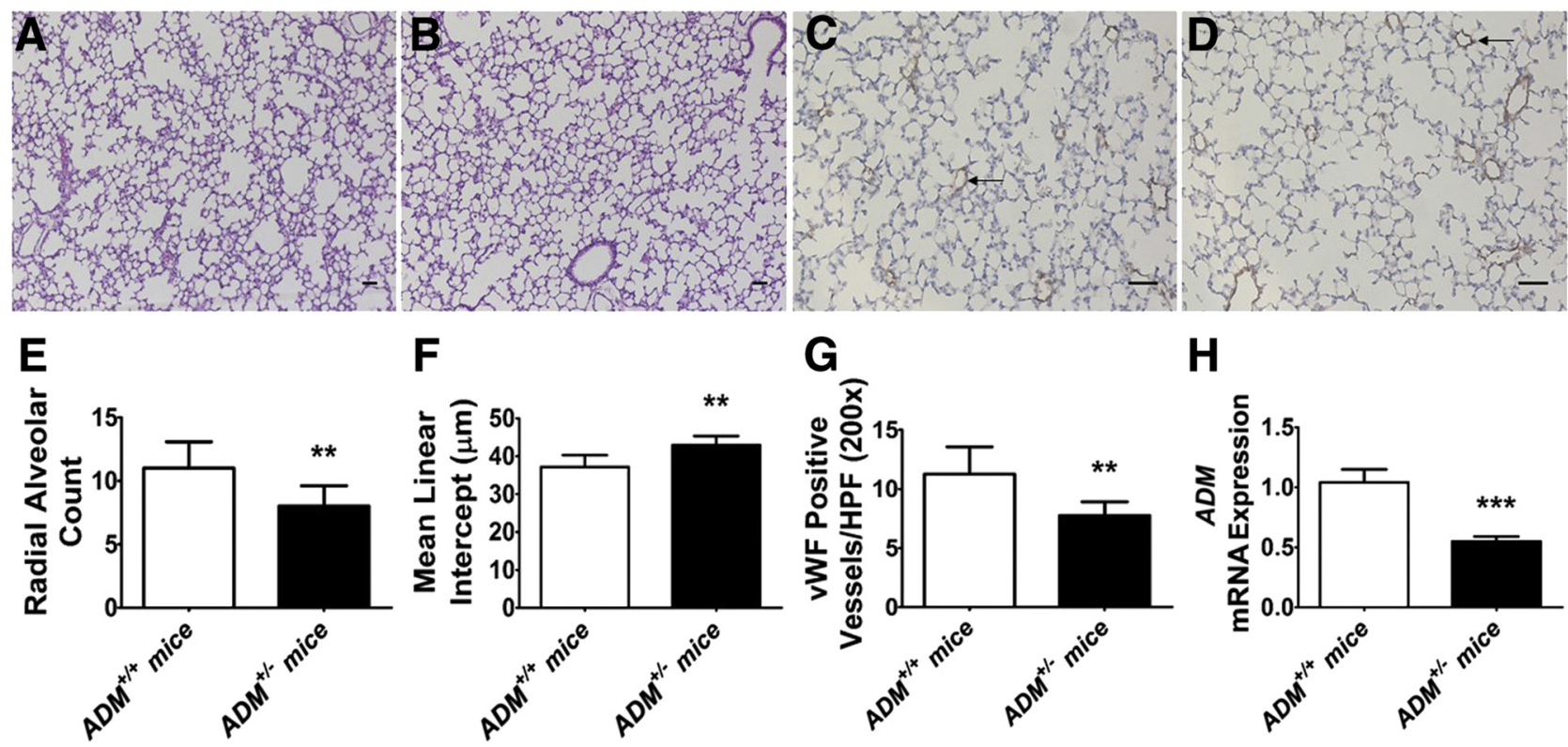

Figure 1 Deficits in alveolarization and lung vascularization of 2-week-old adrenomedullin-deficient $\left(A D M^{+/-}\right)$mice. Lung tissues of mice exposed to $21 \%$ oxygen (normoxia) were harvested on postnatal day 14 for lung morphometry and gene expression assays. A and B: Representative hematoxylin and eosin-stained lung sections obtained from adrenomedullin-sufficient $\left(A D M^{+/+}\right)(\mathbf{A})$ and $A D M^{+/-}(\mathbf{B})$ mice. C and D: Representative von Willebrand factor (VWF)-immunostained lung sections (arrows) obtained from $A D M^{+/+}$(C) and $A D M^{+/-}$(D) mice. E-G: Alveolarization was quantified by determining radial alveolar counts $(\mathbf{E})$ and mean linear intercepts $(\mathbf{F})$, and pulmonary vascularization was quantified by counting the vWF-stained lung blood vessels $(\mathbf{G})$. H: RTPCR analyses-based determination of $A D M$ mRNA levels. Data are expressed as means \pm SD. $n=5$ to 8 mice per group. ${ }^{* *} P<0.01$, ${ }^{* * *} P<0.001$ versus $A D M^{+/+}$mice ( $t$-test). Scale bars $=100 \mu \mathrm{m}$. HPF, high-power field. 

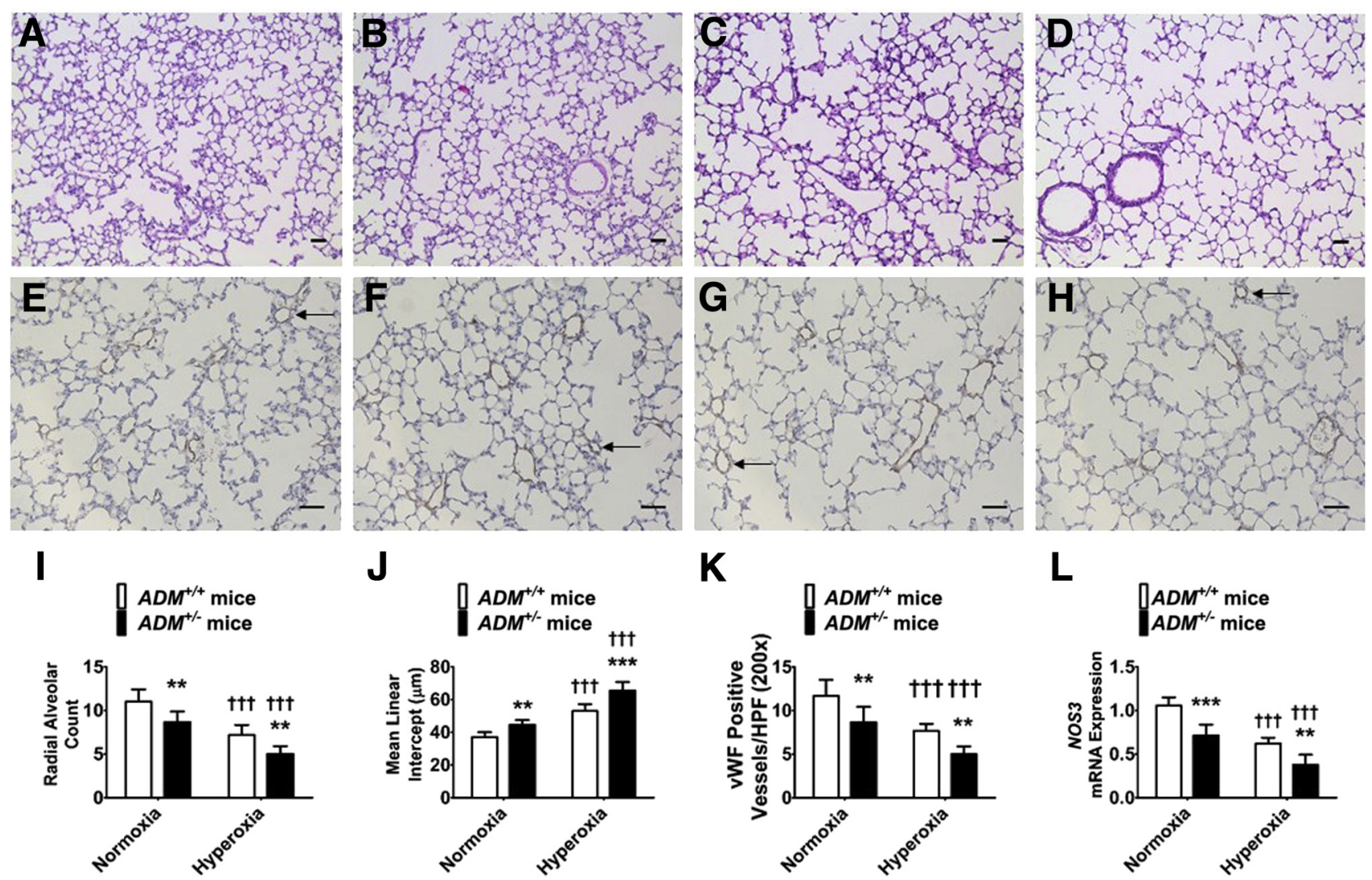

Figure 2 Deficits in alveolarization and lung vascularization of 2-week-old adrenomedullin-deficient ( $A D M^{+/-}$) mice exposed to hyperoxia. Adrenomedullin-sufficient $\left(\mathrm{ADM}^{+/+}\right)$or $A D M^{+/-}$mice were exposed to $21 \%$ oxygen (normoxia) or $70 \%$ oxygen (hyperoxia) for 2 weeks, and their lung tissues were collected on postnatal day (PND) 14 for lung and pulmonary vascular morphometry. A-D: Representative hematoxylin and eosin-stained lung sections from $\mathrm{ADM}^{+/+}(\mathbf{A}$ and $\mathbf{C})$ and $A D M^{+/-}$(B and $\left.\mathbf{D}\right)$ mice exposed to normoxia (A and $\left.\mathbf{B}\right)$ or hyperoxia (C and $\left.\mathbf{D}\right)$. E-H: Representative von Willebrand factor (vWF)immunostained lung sections (arrows) from $A D M^{+/+}(\mathbf{E}$ and $\mathbf{G})$ and $A D M^{+/-}(\mathbf{F}$ and $\mathbf{H})$ mice exposed to normoxia $(\mathbf{E}$ and $\mathbf{F})$ or hyperoxia $(\mathbf{G}$ and $\mathbf{H})$. I- $\mathbf{K}$ : Alveolarization was quantified by determining radial alveolar counts (I) and mean linear intercepts (J), and pulmonary vascularization was quantified by counting the vWF-stained lung blood vessels (K). L: RT-PCR analyses-based determination of NOS3 mRNA levels on PND7. Data are expressed as means \pm SD. $n=6$ mice per group. ${ }^{*} P<0.01,{ }^{* * *} P<0.001$ versus $A D M^{+/+}$mice; ${ }^{\dagger \dagger} P<0.001$ versus normoxia. Scale bars $=100 \mu \mathrm{m}$. HPF, high-power field.

were measured to determine the effects of the $A D M$ gene, neonatal hyperoxia exposure, and their interactions on the magnitude of PH at PND28. Hyperoxia decreased PAT (Figure 4, A-E) and the PAT/ET ratio (Figure 4, A-D and $\mathrm{F}$ ) and increased the estimated RVSP (Figure $4 \mathrm{G}$ ) in adolescent mice compared with normoxia-exposed mice. These effects of hyperoxia were significantly greater in $A D M^{+/-}$mice than $A D M^{+/+}$mice (Figure 4). Hyperoxia did not affect the heart rate (Figure $4 \mathrm{H}$ ) in these experimental animals.

\section{AM Signaling Is Necessary to Resolve Experimental PH Caused by Neonatal Hyperoxia}

Previous studies with C57BL6J wild-type mice suggested that experimental $\mathrm{PH}$ caused by neonatal hyperoxia exposure persists at PND56. ${ }^{25}$ As a result, echocardiographic studies were performed at PND70 to determine whether AM is necessary for the resolution of neonatal hyperoxia-induced experimental PH. Neonatal hyperoxia decreased PAT
(Figure 5, A-E) and the PAT/ET ratio (Figure 5, A-D and F) and increased the estimated RVSP (Figure 5G) at PND70 in $A D M^{+/-}$mice compared with normoxia-exposed mice. In contrast, the adverse effects of neonatal hyperoxia on the indexes of $\mathrm{PH}$ resolved in $A D M^{+/+}$mice (Figure 5). Consistent with findings at PND28, hyperoxia did not have an effect on the heart rate in experimental animals (Figure $5 \mathrm{H}$ ).

\section{$A D M^{+/-}$Mice Display Increased and Delayed Resolution of Lung Apoptosis on Exposure to Neonatal Hyperoxia}

To determine the extent of hyperoxia-induced lung injury, we quantified the severity of lung apoptosis by gene and protein expression assays. At PND7, hyperoxia exposure increased the mRNA expression of $B A X$ (Figure 6A) and TNFRSF10B (Figure 6B), the genes mediating the intrinsic and extrinsic apoptotic pathways, respectively, in the lungs of both $A D M^{+/+}$and $A D M^{+/-}$mice. However, the mRNA 


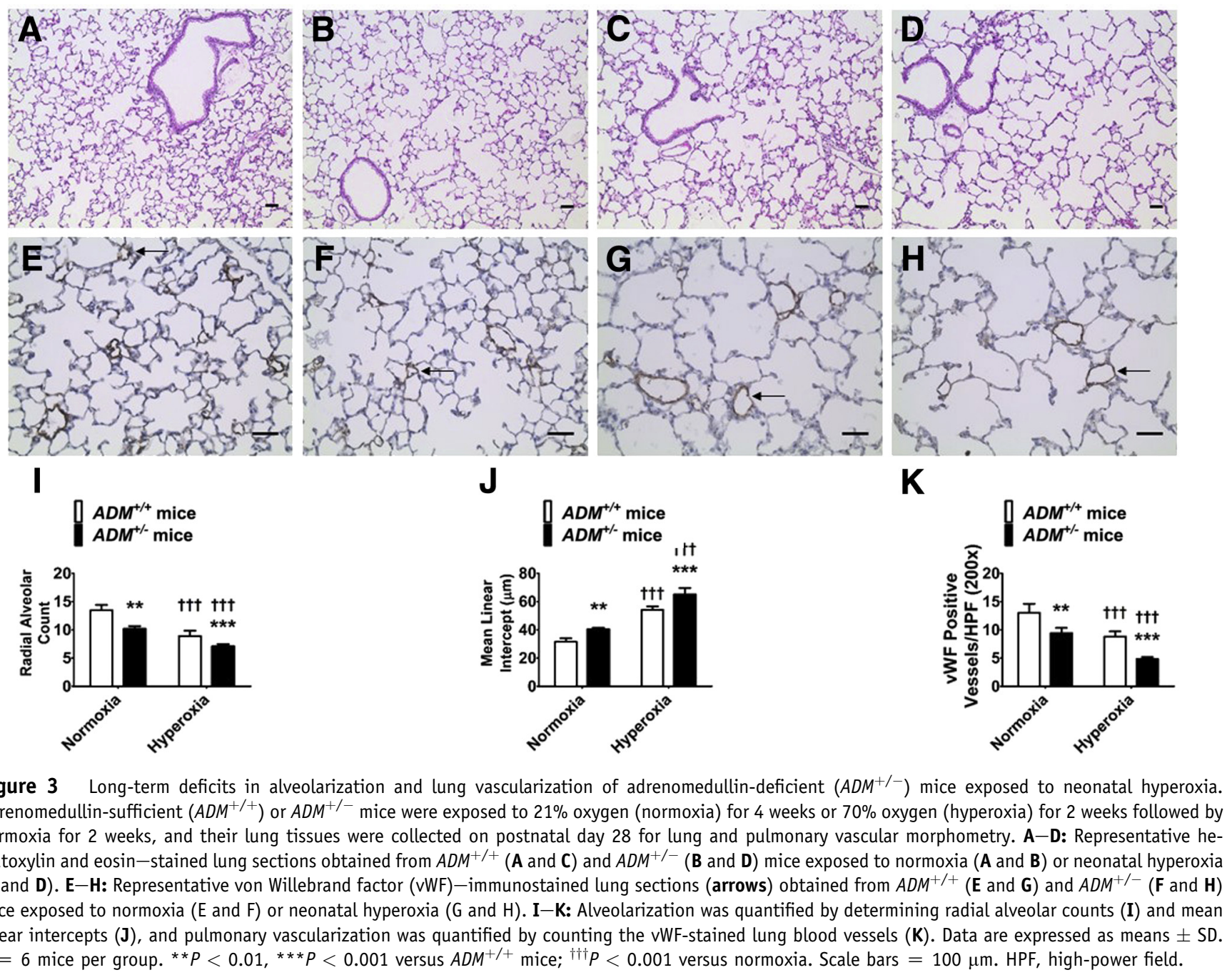

Figure 3 Long-term deficits in alveolarization and lung vascularization of adrenomedullin-deficient $\left(A D M^{+/-}\right)$mice exposed to neonatal hyperoxia. Adrenomedullin-sufficient $\left(A D M^{+/+}\right.$) or $A D M^{+/-}$mice were exposed to $21 \%$ oxygen (normoxia) for 4 weeks or $70 \%$ oxygen (hyperoxia) for 2 weeks followed by normoxia for 2 weeks, and their lung tissues were collected on postnatal day 28 for lung and pulmonary vascular morphometry. A-D: Representative hematoxylin and eosin-stained lung sections obtained from $\mathrm{ADM}^{+/+}(\mathbf{A}$ and $\mathbf{C})$ and $A D M^{+/-}(\mathbf{B}$ and $\mathbf{D})$ mice exposed to normoxia $(\mathbf{A}$ and $\mathbf{B})$ or neonatal hyperoxia (C and $\mathbf{D})$. E-H: Representative von Willebrand factor (vWF)-immunostained lung sections (arrows) obtained from $A^{+} M^{+/+}(\mathbf{E}$ and $\mathbf{G})$ and $A D M^{+/-}(\mathbf{F}$ and $\mathbf{H})$ mice exposed to normoxia (E and F) or neonatal hyperoxia $(\mathrm{G}$ and $\mathrm{H})$. I-K: Alveolarization was quantified by determining radial alveolar counts (I) and mean linear intercepts $(\mathbf{J})$, and pulmonary vascularization was quantified by counting the vWF-stained lung blood vessels (K). Data are expressed as means \pm SD. $n=6$ mice per group. ${ }^{*} P<0.01,{ }^{* *} P<0.001$ versus $A D M^{+/+}$mice; ${ }^{\dagger \dagger} P<0.001$ versus normoxia. Scale bars $=100 \mu \mathrm{m}$. HPF, high-power field.

levels of both these genes decreased to baseline in hyperoxia-exposed $A D M^{+/+}$mice at PND14 (Figure 6, A and B). In contrast, TNFRSF1OB mRNA levels remained elevated in hyperoxia-exposed $A D M^{+/-}$mice compared with controls at PND14 (Figure 6B). Consistent with the gene expression results, cleaved caspase 3 protein expression at PND14 was significantly increased in $A D M^{+/-}$than in $A D M^{+/+}$mice on hyperoxia exposure (Figure 6, C and D).

\section{$A D M^{+/-}$Mice Have Increased Lung Collagen Content on Neonatal Hyperoxia Exposure}

The magnitude of hyperoxia-induced lung injury was estimated by quantifying the lung collagen content by immunohistochemistry studies. Neonatal hyperoxia exposure increased the percent area of lung collagen staining at PND14 (Figure 7, A, B, C, D, and I). Furthermore, the lung collagen content continued to increase in adolescent mice exposed to neonatal hyperoxia
(Figure 7, E-I). Importantly, these effects of neonatal hyperoxia were more significantly augmented in $A D M^{+/-}$ than in $A D M^{+/+}$mice (Figure 7), indicating that endogenous AM signaling modulates hyperoxia-mediated neonatal lung injury.

\section{AM Signaling Is Necessary for HPMEC Tubule Formation}

AM promotes fetal HPMEC tubule formation and migration, ${ }^{32}$ indicating that AM may also promote lung angiogenesis in infants. Whether AM signaling is necessary for lung angiogenesis and how AM promotes angiogenesis in infants are unclear. To address these gaps, siRNAs were used to knockdown ADM, Calcrl, RAMP2, and Calcrl + RAMP2 genes in HPMECs. siRNA transfections decreased the mRNA expression of the target genes by greater than twofold (Figure 8, A-C), and knockdown of $A M$, Calcrl, RAMP2, and Calcrl + RAMP2 decreased HPMEC tubule formation (Figure 8, D-K). Importantly, knockdown of both the receptors that are crucial for $A D M$ 
A

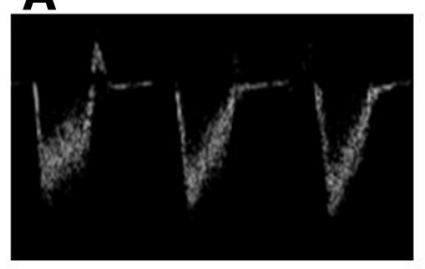

E

$A D M^{+/+}$mice
$A D M^{+/-}$mice

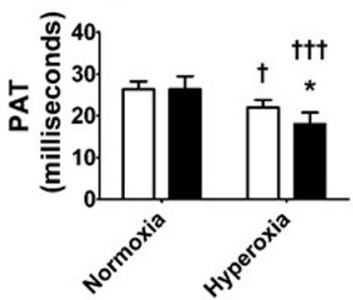

B

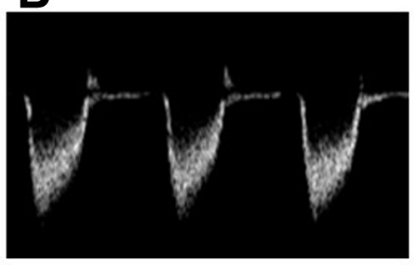

F
C

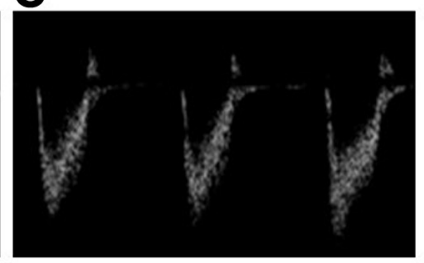

G

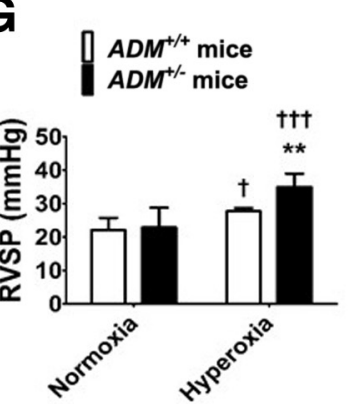

D

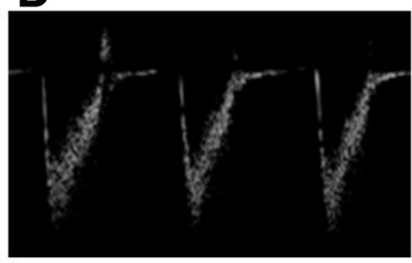

H
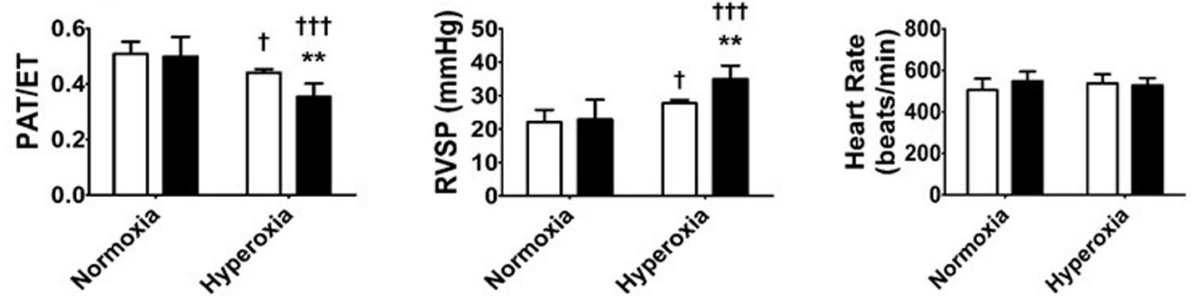

Figure 4 Indexes of pulmonary hypertension at postnatal day (PND) 28 in adrenomedullin-deficient $\left(A D M^{+/-}\right)$mice exposed to neonatal hyperoxia: Highresolution echocardiographic studies were performed at PND28 on adrenomedullin-sufficient $\left(A D M^{+/+}\right.$) or $A D M^{+/-}$mice exposed to $21 \%$ oxygen (normoxia) for 4 weeks or 70\% oxygen (hyperoxia) for 2 weeks followed by normoxia for 2 weeks. A-D: Representative pulsed-wave Doppler (PWD) echocardiographic recordings of pulmonary artery blood flow obtained from $A D M^{+/+}(\mathbf{A}$ and $\mathbf{C})$ and $A D M^{+/-}$(B and $\left.\mathbf{D}\right)$ mice exposed to normoxia $(\mathbf{A}$ and $\mathbf{B})$ or neonatal hyperoxia (C and D). E-H: Pulmonary acceleration time (PAT) (E), PAT/ejection time (ET) ratio (F), right ventricle systolic pressure (RVSP) (G), and heart rate (H) were estimated from the PWD echocardiographic recordings of the pulmonary artery blood flow. Data are expressed as means \pm SD. $n=4$ to 8 mice per group. ${ }^{\star} P<0.05,{ }^{* *} P<0.01$ versus $A D M^{+/+}$mice; ${ }^{\dagger} P<0.05,{ }^{\dagger \dagger \dagger} P<0.001$ versus normoxia.

signaling had the most profound effect on HPMEC tubule formation (Figure $8 \mathrm{~K}$ ). These findings emphasize that AM signaling is necessary for lung angiogenesis in infants, a notion supported by other investigators ${ }^{19}$ and in vivo data (Figure 1).

\section{AM Promotes HPMEC Tubule Formation via NOS3- Mediated Mechanisms}

To determine how AM promotes angiogenesis, the following experiments were performed. Initially, siRNAs were used to
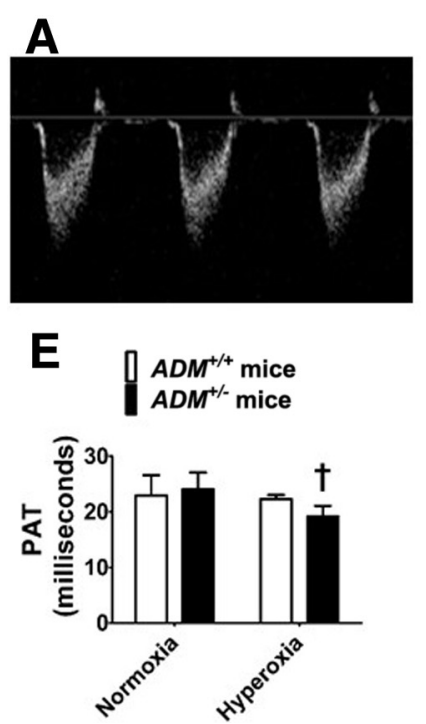
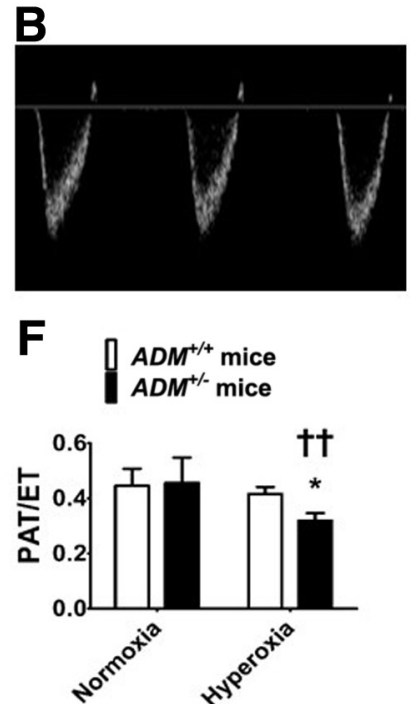
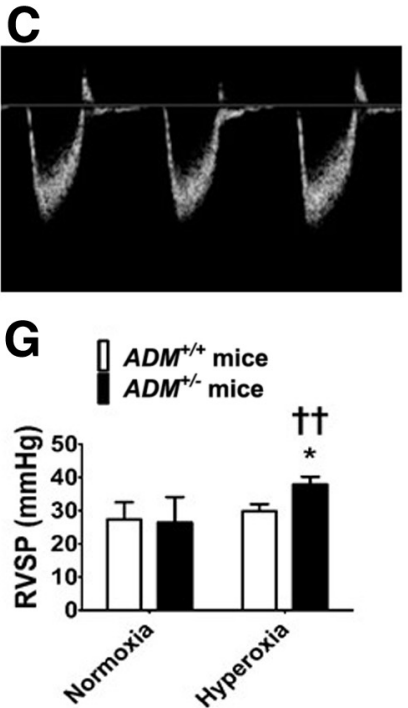

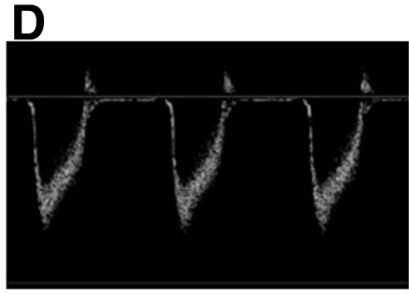

H
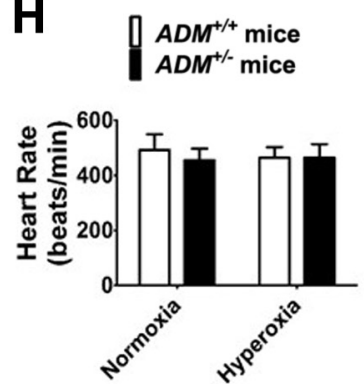

Figure 5 Indexes of pulmonary hypertension at postnatal day (PND) 70 in adrenomedullin-deficient $\left(A D M^{+/-}\right)$mice exposed to neonatal hyperoxia. Highresolution echocardiographic studies were performed on PND70 on adrenomedullin-sufficient $\left(A D M^{+/+}\right)$or $A D M^{+/-}$mice exposed to $21 \%$ oxygen (normoxia) for 10 weeks or 70\% oxygen (hyperoxia) for 2 weeks followed by normoxia for 8 weeks. A-D: Representative pulsed-wave Doppler (PWD) echocardiographic recordings of pulmonary artery blood flow obtained from $A D M^{+/+}(\mathbf{A}$ and $\mathbf{C})$ and $A D M^{+/-}$(B and $\left.\mathbf{D}\right)$ mice exposed to normoxia $(\mathbf{A}$ and $\mathbf{B})$ or neonatal hyperoxia (C and D). E-H: Pulmonary acceleration time (PAT) (E), PAT/ejection time (ET) ratio (F), RIGHT ventricle systolic pressure (RVSP) (G), and heart rate (H) were estimated from the PWD echocardiographic recordings of the pulmonary artery blood flow. Data are expressed as means \pm SD. $n=4$ to 8 mice per group. ${ }^{*} P<0.05$ versus $A D M^{+/+}$mice; ${ }^{\dagger} P<0.05,{ }^{\dagger} P<0.01$ versus normoxia. 

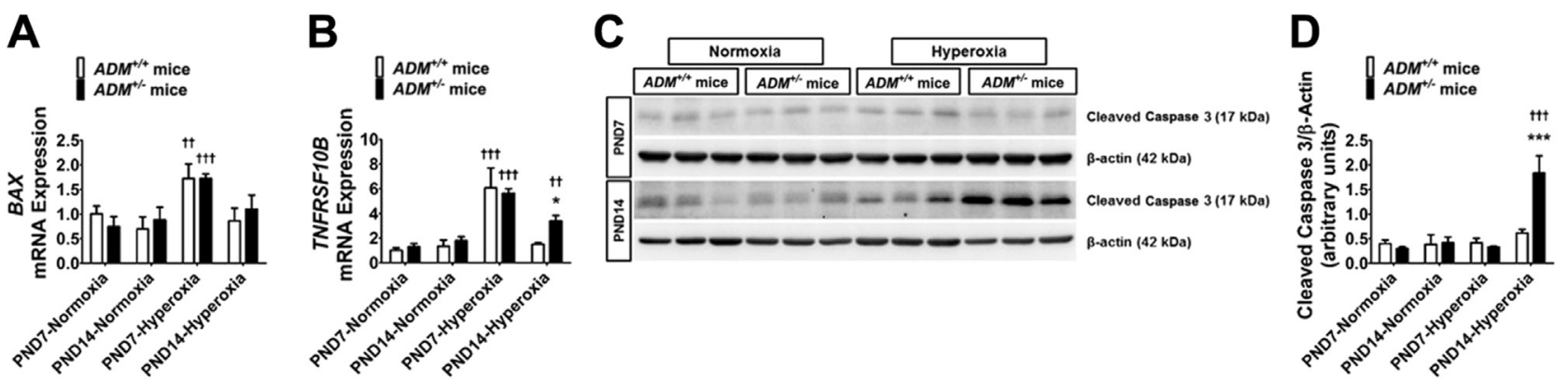

Figure 6 Quantification of apoptosis in the lungs of neonatal adrenomedullin-deficient $\left(A D M^{+/-}\right)$mice exposed to hyperoxia. Lung tissues of mice exposed to $21 \%$ oxygen (normoxia) or $70 \%$ oxygen (hyperoxia) were collected on postnatal day (PND) 7 or PND14 for gene and protein expression assays. A and B: RTPCR analyses-based determination of BAX (A) and TNFRSF1OB (B) mRNA levels. C: Determination of cleaved caspase 3 protein levels by immunoblotting. D: Quantification and normalization of cleaved caspase 3 band intensities to those of $\beta$-actin. Data are expressed as means \pm SD. $n=3$ mice per group. ${ }^{*} P<0.05,{ }^{* * *} P<0.001$ versus $A D M^{+/+}$mice; ${ }^{\dagger \dagger} P<0.01,{ }^{\dagger \dagger \dagger} P<0.001$ versus normoxia.

knockdown $A D M$, Calcrl, and RAMP2 genes in HPMECs and determined its effects on NOS3 mRNA expression and nitric oxide generation. Knockdown of $A D M$ or its signaling receptors decreased NOS3mRNA expression by greater than twofold (Figure 9A). Next, the nitric oxide generation by these cells was quantified using the nitric oxide-sensitive fluorescent probe, DAF-FM diacetate. Control siRNA-transfected cells were capable of generating nitric oxide in response to the calcium ionophore, A23187, whereas the cells deficient in $A D M$ or its signaling receptors, $C a l c r l$ and $R A M P 2$, failed to similarly increase nitric oxide generation with A23187 treatment (Figure 9B). These findings indicate that $A D M$ regulates
NOS3signaling in lung endothelial cells. Finally, to determine whether $A D M$ mediates angiogenesis via NOS3, NOS3 protein expression by NOS3 siRNA was inhibited (Figure 9, C and $\mathrm{D})$ before treating the cells with AM. The angiogenic effect of AM was attenuated when NOS3 signaling was inhibited (Figure 9, E-I).

\section{Discussion}

This study examined the: long-term effects of the $A D M$ gene and neonatal hyperoxia exposure and the interactions
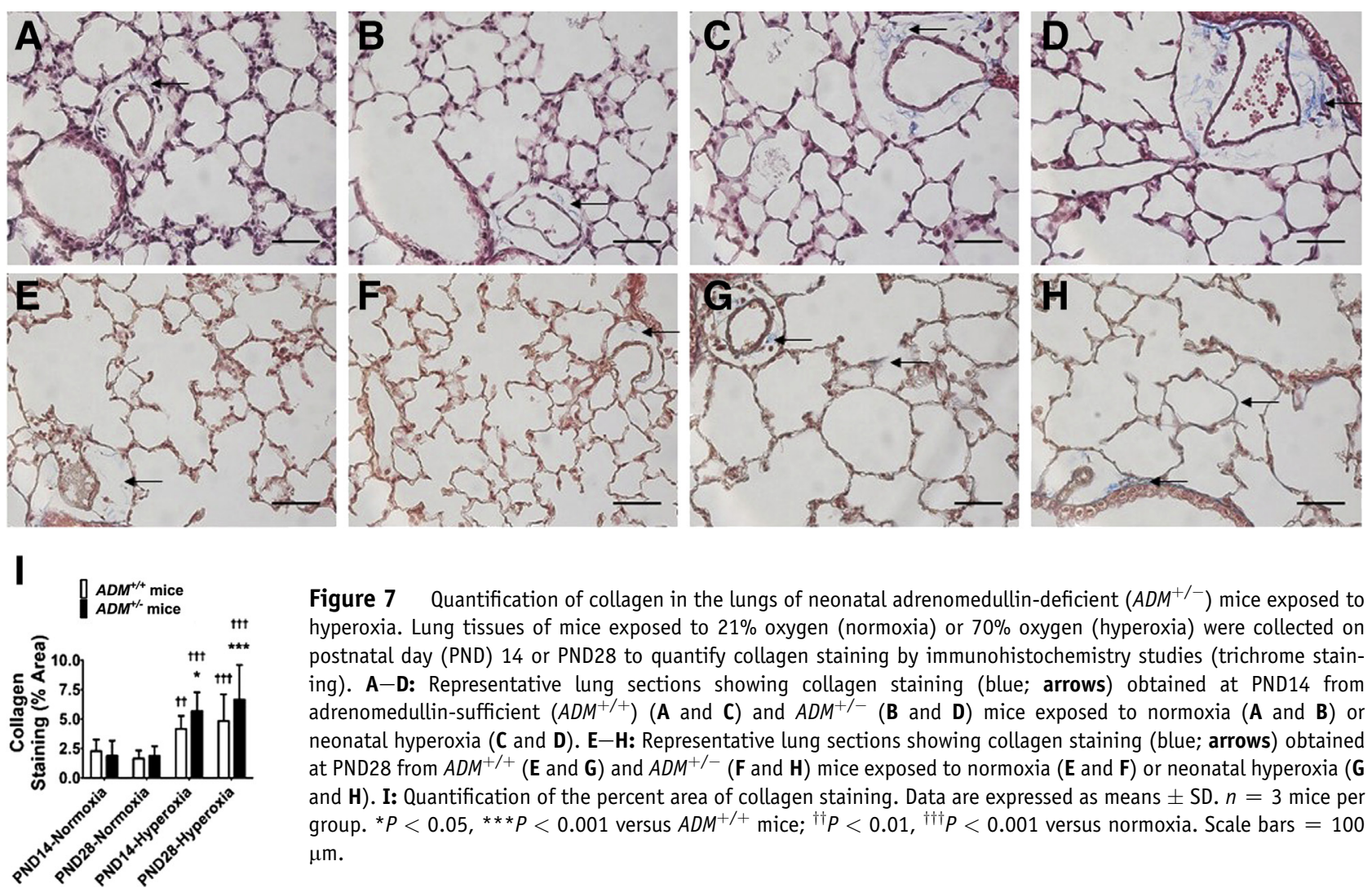

Figure 7 Quantification of collagen in the lungs of neonatal adrenomedullin-deficient $\left(A D M^{+/-}\right)$mice exposed to hyperoxia. Lung tissues of mice exposed to $21 \%$ oxygen (normoxia) or $70 \%$ oxygen (hyperoxia) were collected on postnatal day (PND) 14 or PND28 to quantify collagen staining by immunohistochemistry studies (trichrome staining). A-D: Representative lung sections showing collagen staining (blue; arrows) obtained at PND14 from adrenomedullin-sufficient $\left(A D M^{+/+}\right)(\mathbf{A}$ and $\mathbf{C})$ and $A D M^{+/-}(\mathbf{B}$ and $\mathbf{D})$ mice exposed to normoxia $(\mathbf{A}$ and $\mathbf{B})$ or neonatal hyperoxia ( $\mathbf{C}$ and $\mathbf{D})$. E-H: Representative lung sections showing collagen staining (blue; arrows) obtained at PND28 from $A_{D M}{ }^{+/+}$(E and $\mathbf{G}$ ) and $A D M^{+/-}(\mathbf{F}$ and $\mathbf{H}$ ) mice exposed to normoxia (E and $\mathbf{F}$ ) or neonatal hyperoxia ( $\mathbf{G}$ and $\mathbf{H}$ ). I: Quantification of the percent area of collagen staining. Data are expressed as means \pm SD. $n=3$ mice per group. ${ }^{*} P<0.05,{ }^{* *} P<0.001$ versus $A D M^{+/+}$mice; ${ }^{\dagger \dagger} P<0.01,{ }^{\dagger \dagger \dagger} P<0.001$ versus normoxia. Scale bars $=100$ $\mu \mathrm{m}$. 

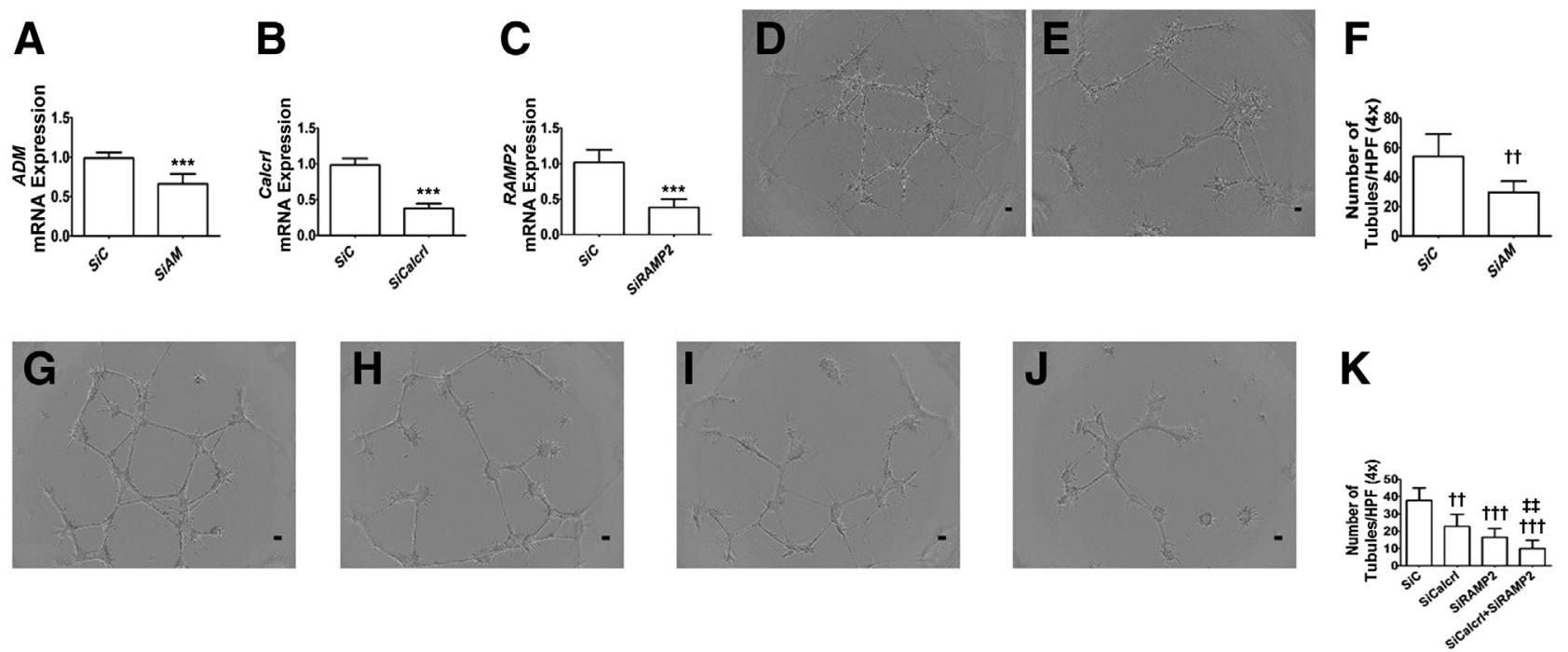

Figure 8 Effects of adrenomedullin (AM) signaling on human pulmonary microvascular endothelial cell (HPMEC) tubule formation. siRNA-transfected HPMECs were harvested for gene expression and tubule formation assays. A-C: RT-PCR analyses-based determination of ADM (A), Calcrl (B), and RAMP2 (C) mRNA levels. D and E: Representative images showing tubule formation of cells transfected with control (D) and ADM (E) siRNAs. F: Quantification of tubule formation in control (SiC) and ADM (SiAM) siRNA-transfected cells. G-J: Representative images showing tubule formation of cells transfected with control (G), Calcrl (H), RAMP2 (I), and Calcrl + RAMP2 (J) siRNAs. K: Quantification of tubule formation in control (SiC), Calcrl (SiCalcrl), RAMP2 (SiRAMP2), and Calcrl + RAMP2 (SiCalcrl + SiRAMP2) siRNA-transfected cells. Data are expressed as means \pm SD. $n=5$ to 7 per group. ${ }^{* * * P}<0.001$ versus SiC $(t$-test); ${ }^{\dagger \dagger} P<0.01,{ }^{\dagger \dagger} P<0.001$ versus control siRNA-transfected cells; ${ }^{\ddagger \ddagger} P<0.01$ versus all other groups. Scale bars $=100 \mu \mathrm{m}$. HPF, high-power field.

between them on lung development and pulmonary vascular function in mice and mechanistic roles of AM signaling in infantile lung angiogenesis. These findings demonstrate that $A D M$ deficiency in neonatal mice decreases lung NOS3 mRNA expression and impairs resolution of hyperoxiainduced experimental BPD and PH. Furthermore, it is observed that $A D M$ signaling is necessary for lung angiogenesis and AM may promote angiogenesis via NOS3.

Pulmonary vasculature plays a major role in the maintenance of lung health. Developmental lung disorders, such as BPD, are characterized by the disruption of lung angiogenesis. ${ }^{38}$ Lung angiogenesis is necessary for alveolarization,
A

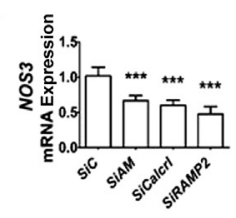

B

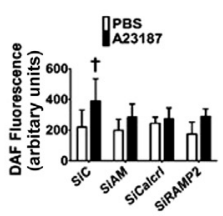

C

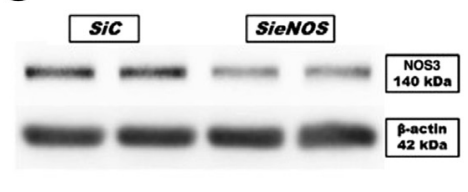

D

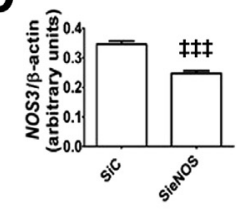

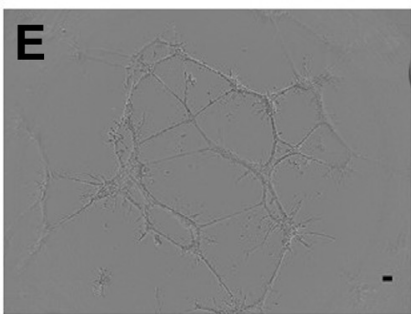
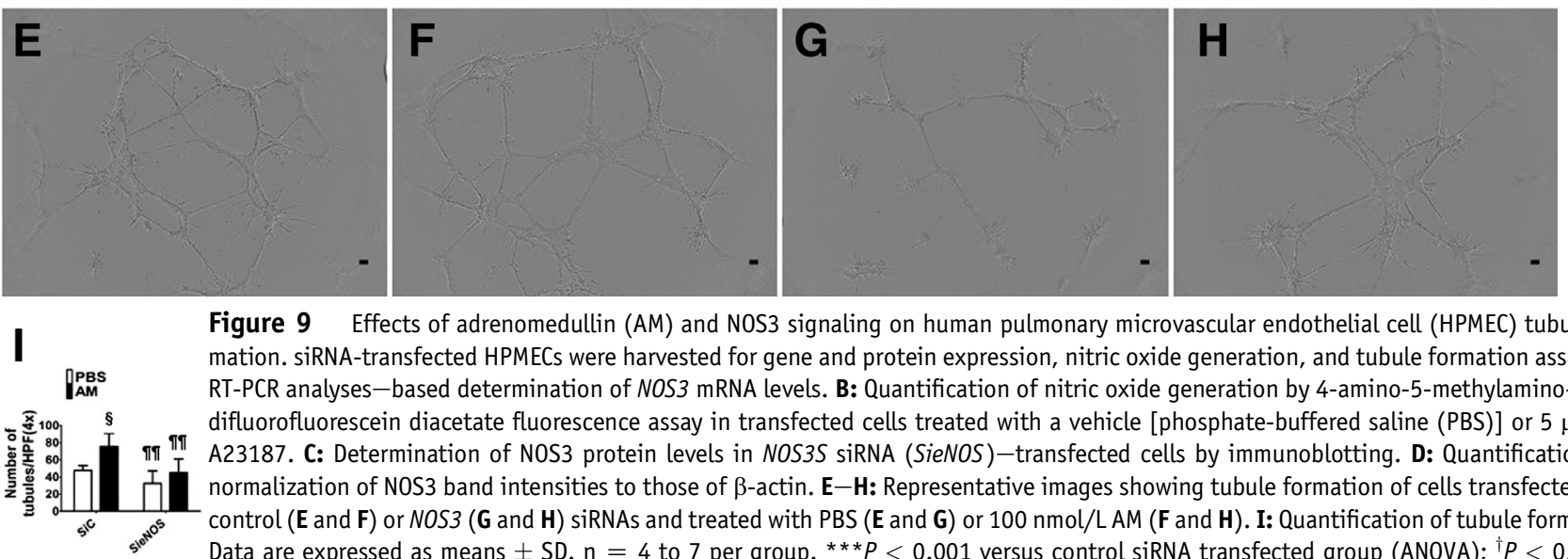

Figure 9 Effects of adrenomedullin (AM) and NOS3 signaling on human pulmonary microvascular endothelial cell (HPMEC) tubule formation. siRNA-transfected HPMECs were harvested for gene and protein expression, nitric oxide generation, and tubule formation assays. A: RT-PCR analyses-based determination of NOS3 mRNA levels. B: Quantification of nitric oxide generation by 4-amino-5-methylamino- $2^{\prime}, 7^{\prime}$ difluorofluorescein diacetate fluorescence assay in transfected cells treated with a vehicle [phosphate-buffered saline (PBS)] or $5 \mu \mathrm{mol} / \mathrm{L}$ A23187. C: Determination of NOS3 protein levels in NOS3S siRNA (SieNOS)-transfected cells by immunoblotting. D: Quantification and normalization of NOS3 band intensities to those of $\beta$-actin. E-H: Representative images showing tubule formation of cells transfected with control ( $\mathbf{E}$ and $\mathbf{F}$ ) or NOS3 ( $\mathbf{G}$ and $\mathbf{H}$ ) siRNAs and treated with PBS (E and $\mathbf{G}$ ) or $100 \mathrm{nmol} / \mathrm{L} \mathrm{AM} \mathrm{(F} \mathrm{and} \mathbf{H})$. I: Quantification of tubule formation. Data are expressed as means \pm SD. $\mathrm{n}=4$ to 7 per group. ${ }^{* *} P<0.001$ versus control siRNA transfected group (ANOVA); ${ }^{\dagger} P<0.05$ for differences among groups for nitric oxide generation (analysis of variance); ${ }^{\ddagger \ddagger} P<0.001$ versus control siRNA transfected group ( $t$-test); ${ }^{\S} P<0.05$ versus PBS-treated cells for tubule formation; ${ }^{\top \uparrow} P<0.01$ versus SiC-transfected cells for tubule formation. Scale bars $=100 \mu \mathrm{m}$. 
and disrupted angiogenesis during lung development causes interrupted alveolarization. ${ }^{26,39}$ Therefore, findings of decreased lung vascularization in $A D M$-deficient mice (Figure 1) indicate that $A D M$ is necessary for normal lung development, a conclusion supported by other preclinical studies. ${ }^{14,16,19}$

Hyperoxia exposure disrupts signaling pathways necessary for lung development and repair ${ }^{40,41}$ and interrupts alveolarization and pulmonary vascularization in preterm infants $^{42}$ and newborn mice. ${ }^{43}$ Furthermore, the aberrant lung structure and function of the infants with BPD persist into adolescence. ${ }^{44}$ In addition, hyperoxia-induced experimental BPD and PH phenotype in mice persist up to PND56 ${ }^{25}$; therefore, the effects of the $A D M$ gene and neonatal hyperoxia exposure on the morphologic features of alveoli and pulmonary vasculature and function were assessed in experimental animals up to PND70. These findings (Figures 2 and 3) indicate that neonatal hyperoxia exposure disrupts NOS3 signaling and repair mechanisms in murine lungs and causes persistent deficits in alveolarization and pulmonary vascularization and that $\mathrm{AM}$ signaling is necessary to mitigate these persistent lung developmental deficits.

Noninvasive imaging techniques, such as echocardiography, have been increasingly used to phenotype cardiac structure and function in mice because of the technical limitations of performing cardiac catheterization in neonatal mice. Tricuspid regurgitation that is frequently used to estimate pulmonary arterial pressure by echocardiography rarely occurs in mice; therefore, RV systolic intervals, such as PAT and ET, obtained by pulsed-wave Doppler echocardiography are used as alternative indexes of pulmonary artery pressure. ${ }^{24,31,45}$ In preclinical and clinical studies, both PAT and the PAT/ET ratio inversely correlate with pulmonary artery pressures. ${ }^{45-48}$ Furthermore, RVSP directly correlates with pulmonary artery pressures and can be reliably estimated from the systolic intervals obtained by rodent echocardiographic studies. ${ }^{25,31}$ These observations (Figures 4 and 5) indicate that neonatal hyperoxia-induced PH resolves by PND70 in wild-type mice. Importantly, it is demonstrated that $A D M$ deficiency potentiates $\mathrm{PH}$ and is necessary to resolve this vascular phenotype induced by neonatal hyperoxia in mice. Several studies have found the necessary and sufficient function of AM to prevent and/or treat $\mathrm{PH}$ associated with several lung and heart diseases. ${ }^{49-52}$ This study validates and extends the translational potential of this protective effect of $\mathrm{AM}$ on pulmonary vasculature for BPD-associated $\mathrm{PH}$.

Apoptosis and increased collagen accumulation are markers of tissue injury. At PND14, the apoptotic markers returned to baseline in wild-type mice exposed to hyperoxia, whereas they remained elevated in similarly exposed $A D M$ deficient mice (Figure 6). In contrast to apoptosis, collagen accumulation continued to increase in hyperoxia-exposed animals; however, $A D M$ deficiency augmented the extent of this hyperoxia effect (Figure 7). These observations suggest that $A D M$ plays an important role in the resolution of apoptosis and the accompanying lung tissue injury, a finding that is congruent with a study performed in neonatal rats. $^{19}$

Nitric oxide generated by NOS3 promotes angiogenesis and alveolarization, ${ }^{53-55}$ mediates vasodilation, ${ }^{56}$ prevents vascular smooth muscle proliferation, and inhibits vascular inflammation. ${ }^{57-59}$ Thus, disrupting this pathway could contribute to BPD and PH. Although NOS3may mediate the biological effects of $\mathrm{AM},{ }^{17,18}$ whether $\mathrm{AM}$ interacts with this gene during lung development, injury, and repair is unknown. These studies indicate that AM promotes lung angiogenesis partly via NOS3-mediated mechanisms (Figures 8 and 9). It is also possible that AM modulates lung injury by regulating lung epithelial cell proliferation ${ }^{60}$ and apoptosis. $^{13}$

This study i) examined the role of AM in the resolution of hyperoxia-induced developmental lung injury, which has a high translational impact; ii) used echocardiography to identify the impact of AM on pulmonary vascular function; and iii) used fetal HPMECs to demonstrate the mechanistic role of $A D M$ in infantile lung angiogenesis. However, this study has a few limitations. First, this study was not designed to examine sex- or cell-specific effects of AM in the developing lungs. Second, the effects of our study variables on lung function were not examined. Finally, the effects of interactions between AM and hyperoxia in fetal HPMECs were not evaluated.

In summary, $A D M$ deficiency decreases NOS 3 expression and impairs the resolution of neonatal hyperoxia-induced murine lung injury. In addition, $A D M$ promotes lung angiogenesis in fetal human lung endothelial cells partly via NOS3. Importantly, these data reiterate that AM could be a new therapeutic target to treat BPD-associated $\mathrm{PH}$ in infants.

\section{Acknowledgments}

We thank Pamela Parsons for timely processing of histopathologic slides and Hannah Johnson for helping us obtain images to quantify tubule formation.

\section{References}

1. Jobe AH: Animal models, learning lessons to prevent and treat neonatal chronic lung disease. Front Med (Lausanne) 2015, 2:49

2. Arjaans S, Zwart EAH, Ploegstra MJ, Bos AF, Kooi EMW, Hillege HL, Berger RMF: Identification of gaps in the current knowledge on pulmonary hypertension in extremely preterm infants: a systematic review and meta-analysis. Paediatr Perinat Epidemiol 2018, 32:258-267

3. Berkelhamer SK, Mestan KK, Steinhorn R: An update on the diag nosis and management of bronchopulmonary dysplasia (BPD)-associated pulmonary hypertension. Semin Perinatol 2018, 42:432-443

4. Mourani PM, Abman SH: Pulmonary hypertension and vascular ab normalities in bronchopulmonary dysplasia. Clin Perinatol 2015, 42: 839-855 
5. Hinson JP, Kapas S, Smith DM: Adrenomedullin, a multifunctional regulatory peptide. Endocr Rev 2000, 21:138-167

6. McLatchie LM, Fraser NJ, Main MJ, Wise A, Brown J, Thompson N, Solari R, Lee MG, Foord SM: RAMPs regulate the transport and ligand specificity of the calcitonin-receptor-like receptor. Nature 1998, 393:333-339

7. Fernandez-Sauze S, Delfino C, Mabrouk K, Dussert C, Chinot O, Martin PM, Grisoli F, Ouafik L, Boudouresque F: Effects of adrenomedullin on endothelial cells in the multistep process of angiogenesis: involvement of CRLR/RAMP2 and CRLR/RAMP3 receptors. Int J Cancer 2004, 108:797-804

8. Fritz-Six KL, Dunworth WP, Li M, Caron KM: Adrenomedullin signaling is necessary for murine lymphatic vascular development. J Clin Invest 2008, 118:40-50

9. Marinoni E, Di Iorio R, Alo P, Villaccio B, Alberini A, Cosmi EV: Immunohistochemical localization of adrenomedullin in fetal and neonatal lung. Pediatr Res 1999, 45:282-285

10. Montuenga LM, Martinez A, Miller MJ, Unsworth EJ, Cuttitta F: Expression of adrenomedullin and its receptor during embryogenesis suggests autocrine or paracrine modes of action. Endocrinology 1997, 138:440-451

11. Martinez A, Miller MJ, Unsworth EJ, Siegfried JM, Cuttitta F: Expression of adrenomedullin in normal human lung and in pulmonary tumors. Endocrinology 1995, 136:4099-4105

12. de Vroomen M, Takahashi Y, Gournay V, Roman C, Rudolph AM, Heymann MA: Adrenomedullin increases pulmonary blood flow in fetal sheep. Pediatr Res 1997, 41:493-497

13. Murakami S, Nagaya N, Itoh T, Iwase T, Fujisato T, Nishioka K, Hamada K, Kangawa K, Kimura H: Adrenomedullin regenerates alveoli and vasculature in elastase-induced pulmonary emphysema in mice. Am J Respir Crit Care Med 2005, 172:581-589

14. Wong PF, O WS, Tang F: An ontogenic study of adrenomedullin gene expression in the rat lung, adrenal, kidney, and heart. Endocrine 2012, 41:256-265

15. Ramos CG, Sun X, Johnson EB, Nelson HE, Gonzalez Bosc LV: Adrenomedullin expression in the developing human fetal lung. $\mathrm{J}$ Investig Med 2014, 62:49-55

16. Franco-Montoya ML, Boucherat O, Thibault C, Chailley-Heu B, Incitti R, Delacourt C, Bourbon JR: Profiling target genes of FGF18 in the postnatal mouse lung: possible relevance for alveolar development. Physiol Genomics 2011, 43:1226-1240

17. Abe M, Sata M, Nishimatsu H, Nagata D, Suzuki E, Terauchi Y, Kadowaki T, Minamino N, Kangawa K, Matsuo H, Hirata Y, Nagai R: Adrenomedullin augments collateral development in response to acute ischemia. Biochem Biophys Res Commun 2003, 306:10-15

18. Hamid SA, Baxter GF: A critical cytoprotective role of endogenous adrenomedullin in acute myocardial infarction. J Mol Cell Cardiol 2006, 41:360-363

19. Vadivel A, Abozaid S, van Haaften T, Sawicka M, Eaton F, Chen M, Thebaud B: Adrenomedullin promotes lung angiogenesis, alveolar development, and repair. Am J Respir Cell Mol Biol 2010, 43: $152-160$

20. Zoetis T, Hurtt ME: Species comparison of lung development. Birth Defects Res B Dev Reprod Toxicol 2003, 68:121-124

21. Aslam M, Baveja R, Liang OD, Fernandez-Gonzalez A, Lee C, Mitsialis SA, Kourembanas S: Bone marrow stromal cells attenuate lung injury in a murine model of neonatal chronic lung disease. Am J Respir Crit Care Med 2009, 180:1122-1130

22. Chen S, Rong M, Platteau A, Hehre D, Smith H, Ruiz P, Whitsett J, Bancalari E, Wu S: CTGF disrupts alveolarization and induces pulmonary hypertension in neonatal mice: implication in the pathogenesis of severe bronchopulmonary dysplasia. Am J Physiol Lung Cell Mol Physiol 2011, 300:L330-L340

23. Lee KJ, Berkelhamer SK, Kim GA, Taylor JM, O'Shea KM, Steinhorn RH, Farrow KN: Disrupted pulmonary artery cGMP signaling in mice with hyperoxia-induced pulmonary hypertension. Am J Respir Cell Mol Biol 2014, 50:369-378

24. Reynolds CL, Zhang S, Shrestha AK, Barrios R, Shivanna B: Phenotypic assessment of pulmonary hypertension using highresolution echocardiography is feasible in neonatal mice with experimental bronchopulmonary dysplasia and pulmonary hypertension: a step toward preventing chronic obstructive pulmonary disease. Int J Chron Obstruct Pulmon Dis 2016, 11:1597-1605

25. Menon RT, Shrestha AK, Reynolds CL, Barrios R, Shivanna B: Long-term pulmonary and cardiovascular morbidities of neonatal hyperoxia exposure in mice. Int $\mathrm{J}$ Biochem Cell Biol 2018, 94: $119-124$

26. Thebaud B, Abman SH: Bronchopulmonary dysplasia: where have all the vessels gone? Roles of angiogenic growth factors in chronic lung disease. Am J Respir Crit Care Med 2007, 175:978-985

27. Zhang S, Patel A, Moorthy B, Shivanna B: Adrenomedullin deficiency potentiates hyperoxic injury in fetal human pulmonary microvascular endothelial cells. Biochem Biophys Res Commun 2015, 464:1048-1053

28. Caron KM, Smithies O: Extreme hydrops fetalis and cardiovascular abnormalities in mice lacking a functional adrenomedullin gene. Proc Natl Acad Sci U S A 2001, 98:615-619

29. Shivanna B, Chu C, Welty SE, Jiang W, Wang L, Couroucli XI, Moorthy B: Omeprazole attenuates hyperoxic injury in $\mathrm{H} 441$ cells via the aryl hydrocarbon receptor. Free Radic Biol Med 2011, 51: 1910-1917

30. Shrestha AK, Bettini ML, Menon RT, Gopal VYN, Huang S, Edwards DP, Pammi M, Barrios R, Shivanna B: Consequences of early postnatal lipopolysaccharide exposure on developing lungs in mice. Am J Physiol Lung Cell Mol Physiol 2019, 316:L229-L244

31. Thibault HB, Kurtz B, Raher MJ, Shaik RS, Waxman A, Derumeaux G, Halpern EF, Bloch KD, Scherrer-Crosbie M: Noninvasive assessment of murine pulmonary arterial pressure: validation and application to models of pulmonary hypertension. Circ Cardiovasc Imaging 2010, 3:157-163

32. Menon RT, Shrestha AK, Shivanna B: Hyperoxia exposure disrupts adrenomedullin signaling in newborn mice: implications for lung development in premature infants. Biochem Biophys Res Commun 2017, 487:666-671

33. Caron K, Hagaman J, Nishikimi T, Kim HS, Smithies O: Adrenomedullin gene expression differences in mice do not affect blood pressure but modulate hypertension-induced pathology in males. Proc Natl Acad Sci U S A 2007, 104:3420-3425

34. Wetzel-Strong SE, Li M, Klein KR, Nishikimi T, Caron KM: Epicardial-derived adrenomedullin drives cardiac hyperplasia during embryogenesis. Dev Dyn 2014, 243:243-256

35. Yee M, White RJ, Awad HA, Bates WA, McGrath-Morrow SA, O'Reilly MA: Neonatal hyperoxia causes pulmonary vascular disease and shortens life span in aging mice. Am J Pathol 2011, 178: $2601-2610$

36. Mankouski A, Kantores C, Wong MJ, Ivanovska J, Jain A, Benner EJ, Mason SN, Tanswell AK, Auten RL, Jankov RP: Intermittent hypoxia during recovery from neonatal hyperoxic lung injury causes long-term impairment of alveolar development: a new rat model of BPD. Am J Physiol Lung Cell Mol Physiol 2017, 312: L208-L216

37. O'Reilly M, Harding R, Sozo F: Altered small airways in aged mice following neonatal exposure to hyperoxic gas. Neonatology 2014 , 105:39-45

38. Bhatt AJ, Pryhuber GS, Huyck H, Watkins RH, Metlay LA, Maniscalco WM: Disrupted pulmonary vasculature and decreased vascular endothelial growth factor, Flt-1, and TIE-2 in human infants dying with bronchopulmonary dysplasia. Am J Respir Crit Care Med 2001, 164:1971-1980

39. McGrath-Morrow SA, Cho C, Cho C, Zhen L, Hicklin DJ, Tuder RM: Vascular endothelial growth factor receptor 2 blockade 
disrupts postnatal lung development. Am J Respir Cell Mol Biol 2005, 32:420-427

40. Silva DM, Nardiello C, Pozarska A, Morty RE: Recent advances in the mechanisms of lung alveolarization and the pathogenesis of bronchopulmonary dysplasia. Am J Physiol Lung Cell Mol Physiol 2015, 309:L1239-L1272

41. Morty RE: Recent advances in the pathogenesis of BPD. Semin Perinatol 2018, 42:404-412

42. Jobe AJ: The new BPD: an arrest of lung development. Pediatr Res 1999, 46:641-643

43. Warner BB, Stuart LA, Papes RA, Wispe JR: Functional and pathological effects of prolonged hyperoxia in neonatal mice. Am J Physiol 1998, 275:L110-L117

44. Cheong JLY, Doyle LW: An update on pulmonary and neurodevelopmental outcomes of bronchopulmonary dysplasia. Semin Perinatol 2018, 42:478-484

45. Urboniene D, Haber I, Fang YH, Thenappan T, Archer SL: Validation of high-resolution echocardiography and magnetic resonance imaging vs. high-fidelity catheterization in experimental pulmonary hypertension. Am J Physiol Lung Cell Mol Physiol 2010, 299: L401-L412

46. Dabestani A, Mahan G, Gardin JM, Takenaka K, Burn C, Allfie A, Henry WL: Evaluation of pulmonary artery pressure and resistance by pulsed Doppler echocardiography. Am J Cardiol 1987, 59:662-668

47. Kitabatake A, Inoue M, Asao M, Masuyama T, Tanouchi J, Morita T, Mishima M, Uematsu M, Shimazu T, Hori M, Abe H: Noninvasive evaluation of pulmonary hypertension by a pulsed Doppler technique. Circulation 1983, 68:302-309

48. Hansmann G, Fernandez-Gonzalez A, Aslam M, Vitali SH, Martin T, Mitsialis SA, Kourembanas S: Mesenchymal stem cell-mediated reversal of bronchopulmonary dysplasia and associated pulmonary hypertension. Pulm Circ 2012, 2:170-181

49. Grieco P, Gomez-Monterrey I: Natural and synthetic peptides in the cardiovascular diseases: an update on diagnostic and therapeutic potentials. Arch Biochem Biophys 2018, 662:15-32

50. Siemsen DW, Dobrinen E, Han S, Chiocchi K, Meissner N, Swain SD: Vascular dysfunction in pneumocystis-associated pulmonary hypertension is related to endothelin response and adrenomedullin concentration. Am J Pathol 2016, 186:259-269

51. Harada-Shiba M, Takamisawa I, Miyata K, Ishii T, Nishiyama N, Itaka K, Kangawa K, Yoshihara F, Asada Y, Hatakeyama K, Nagaya N, Kataoka K: Intratracheal gene transfer of adrenomedullin using polyplex nanomicelles attenuates monocrotaline-induced pulmonary hypertension in rats. Mol Ther 2009, 17:1180-1186

52. Matsui H, Shimosawa T, Itakura K, Guanqun X, Ando K, Fujita T: Adrenomedullin can protect against pulmonary vascular remodeling induced by hypoxia. Circulation 2004, 109:2246-2251

53. Murohara T, Asahara T, Silver M, Bauters C, Masuda H, Kalka C, Kearney M, Chen D, Symes JF, Fishman MC, Huang PL, Isner JM: Nitric oxide synthase modulates angiogenesis in response to tissue ischemia. J Clin Invest 1998, 101:2567-2578

54. Forstermann U, Munzel T: Endothelial nitric oxide synthase in vascular disease: from marvel to menace. Circulation 2006, 113:1708-1714

55. Leuwerke SM, Kaza AK, Tribble CG, Kron IL, Laubach VE: Inhibition of compensatory lung growth in endothelial nitric oxide synthase-deficient mice. Am J Physiol Lung Cell Mol Physiol 2002, 282:L1272-L1278

56. Huang PL, Huang Z, Mashimo H, Bloch KD, Moskowitz MA, Bevan JA, Fishman MC: Hypertension in mice lacking the gene for endothelial nitric oxide synthase. Nature 1995, 377:239-242

57. Hogan M, Cerami A, Bucala R: Advanced glycosylation endproducts block the antiproliferative effect of nitric oxide: role in the vascular and renal complications of diabetes mellitus. J Clin Invest 1992, 90: $1110-1115$

58. Nakaki T, Nakayama M, Kato R: Inhibition by nitric oxide and nitric oxide-producing vasodilators of DNA synthesis in vascular smooth muscle cells. Eur J Pharmacol 1990, 189:347-353

59. Garg UC, Hassid A: Nitric oxide-generating vasodilators and 8-bromo-cyclic guanosine monophosphate inhibit mitogenesis and proliferation of cultured rat vascular smooth muscle cells. J Clin Invest 1989, 83:1774-1777

60. Garcia-Sanmartin J, Larrayoz IM, Martinez A: Adrenomedullin regulates club cell recovery following lung epithelial injury. Histol Histopathol 2016, 31:663-673 